\title{
ANALYSIS OF FACTORS INFLUENCING REPORTED HOUSING MAINTENANCE COSTS IN SWEDEN'S PUBLIC AND PRIVATE RENTAL SECTORS
}

\author{
Henry Gonza MUYINGO a,* \\ ${ }^{a}$ Department of Real Estate and Construction Management, School of Architecture and the Built Envi- \\ ronment, KTH Royal Institute of Technology, Brinellvägen 1, SE-100 44 Stockholm, Sweden
}

Received 5 May 2015; accepted 6 May 2016

\begin{abstract}
The reported maintenance costs per unit area within the public rental housing sector in Sweden are consistently higher than those within the private rental sector. This paper uses crosssectional panel data analysis as well as a questionnaire survey sent to 196 managers in the private and public housing sectors to identify the factors that might explain this divergence. The findings indicate that "fundamental" factors such as the age of the houses or the composition of the tenants cannot explain the observed difference. However how the activities are classified and the timing of the measures are factors that can. The conclusions from the study are that the public companies should act more as the private sector in their accounting; wait longer than they currently do before carrying out some renovations; and that they should be more stringent when determining the resources to spend on large-scale maintenance and/or renovation projects.
\end{abstract}

KEYWORDS: Maintenance costs; Property management; Rental housing; Housing maintenance; Residential flats

\section{INTRODUCTION}

The post-World War 2 housing stock in Europe is aging and with it, a need in several countries to increase the level of new construction and maintenance activities in order to rectify the deterioration (Balaras et al. 2005; Meijer et al. 2009). A majority of the Swedish housing stock (63.8\%) is built before 1971 in comparison to the European average of 52.2\% (see Dol, Haffner 2010: 54). Meanwhile the ratio of new construction in total stock stands at 0.7\% (Baek, Park 2012: 486). During the period 1961-1975, approximately 1.4 million dwellings were constructed in Sweden, many of them in the form of flats (Hall, Vidén 2005). There is a huge maintenance backlog in most of the buildings from this period. However, though a government report (Boverket 2002) emphasised the need to increase maintenance measures in this housing stock, few steps have been taken towards promoting efficiency in housing maintenance in Sweden and there is a lack of research studies focusing on the subject. Raising the energy efficiency levels of this

\footnotetext{
* Corresponding author. E-mail: henry.muyingo@abe.kth.se
}

stock through timely maintenance and renovation measures is also an important means of achieving European Parliament goals for reduced energy use by the year 2020 ( Högberg 2014; Steiner, Ahmadi 2013; Thollander et al. 2012).

In general the quality of the houses within the private and the municipal (public) portfolios in Sweden is comparable and the flats are close to perfect substitutes (Turner 1997; Elsinga, Lind 2013). Various management and renovation strategies in the housing sector have been analysed in studies such as Blomé (2010), Lind et al. (2014), Botta (2005), Lind and Blomé (2012), Högberg et al. (2009) and SABO (2009). However, though Statistics Sweden (2012) shows that reported maintenance costs have consistently been higher per unit housing area within the public sector than in the private sector, the reasons behind have not attracted much attention. Factors such as building characteristics and maintainability influence maintenance levels, but given comparable buildings, these aspects alone cannot explain the variance in the costs reported. This paper takes a broader perspective and presents a descriptive 
analysis of factors, in a Swedish context, that provide some of the answers to the research question:

Why do Swedish public sector housing companies consistently report higher maintenance costs than their counterparts in the private sector?

Research that aims at finding the best predictor of an outcome is primarily conducted using a quantitative approach. A qualitative approach is suitable when the goal of a study is to identify the factors that influence an outcome especially if the most important variables to examine are not known to the researcher. In a situation when the approaches above, each by itself, are not adequate to understand the research problem, then a combination of the two is advisable. This paper is based on a procedure similar to the explanatory sequential mixed method design described in Creswell (2013: 15). Initially a cross-sectional panel data analysis of maintenance costs presented in the financial reports of housing companies in the municipal and the private sectors was carried out. The aim was to investigate whether "fundamental" factors such as the age structure of the houses in the portfolios or the economic situation of the companies could provide a persuasive explanation for the observed difference in maintenance costs in the accounts. Thereafter a questionnaire that arose out of a number of qualitative hypotheses based on the literature review was administered to strengthen the quantitative results. The rationale for choosing this approach is that an analysis based on the accounts of municipal companies is problematic as their compliance with accounting standards and legislation is at times poor (Tagesson, Eriksson 2011). Likewise, answers in a survey can present subjective opinions of the respondents that are difficult to quantify but which, in combination with the quantitative data present a new perspective on a subject that is essential yet hardly researched in Sweden.

A major limitation to the research is that the term maintenance has various interpretations and that the goals of the person reporting the data influence the validity and reliability of the results. There is likelihood that due to convenience sampling the qualitative results obtained are from persons that are passionate about the study thus reducing the possibility to generalise the findings.

The public rental sector is defined in this paper as the housing properties owned by companies connected to the local government (municipal council) or properties that are allocated according to the regulations governing "public utility" housing (Pittini, Laino 2011: 22). Rental dwellings that are not the property of companies in the public sector or tenant-owner cooperatives are classified in this paper as part of the private rental sector (PRS). Sweden does not have housing associations such as those in U.K or the Netherlands otherwise; in this paper, they would have been categorised under the public sector. Officially, there is no "social housing" in Sweden (see Scanlon et al. 2015: 2). Rentfree dwellings as described in Haffner (2012) or second homes owned for investment purposes, a rarity in Sweden, are not included as part of the discussions in this paper. Crook and Kemp (2014: $5-6)$ provides several approaches of how PRS is defined in different countries and in the literature based on criteria such as financing and affordability. About $56 \%$ of the population in Sweden live in flats (Statistics Sweden 2013). Therefore the focus of this paper is on the maintenance of buildings containing this type of dwelling.

The rest of the paper is structured as follows: Section 2 contains a brief presentation of the Swedish rental-housing sector. Section 3 presents a literature review on factors that influence maintenance costs. A presentation of the econometric analysis is contained in section 4 . The results of the questionnaire survey are presented in section 5 . The discussion of the results and conclusion is in section 6 .

\section{THE SWEDISH RENTAL HOUSING SECTOR}

The housing market in Sweden consists of four main tenures: owner-occupied, private rental, public rental, as well as tenant-owner cooperatives (TOCs). The municipal housing companies (MHC) account for about $30 \%$ of the flats, the private rental sector (PRS) for 33\% and the tenant-owner cooperatives account for the remaining 37\% (Ball 2012). There are 290 municipalities in Sweden and about the same number of MHCs (Hedman 2008). They own portfolios that largely comprise of residential properties located within the municipality. A large share of the PRS is in the hands of unlisted property companies with buildings scattered over several municipalities. There is a higher degree of commercial space in these portfolios as compared to those owned by public companies. Of the listed companies in Sweden, only 12 have housing as a component in their investments.

In an effort to combat housing shortages and low housing quality, the Swedish state embarked on a programme- "Million Homes Programme" 
(MHP $)^{1}$, to provide one million dwellings during the period 1965-1975 (Hall, Vidén 2005). Twenty five per cent of the Swedish housing stock is comprised of properties constructed under MHP. Municipal housing companies own $46 \%$ of the flats from this period; $26 \%$ are in the hands of private rental companies and $28 \%$ are the property of tenant-owner cooperatives. Since the 1990s and in line with reforms in other countries in Europe, there have been modifications in the strategic management of the municipal housing portfolio such as the sale of portions of the stock in order to renovate the remaining portfolio (see Andersson, Turner 2014; Scanlon et al. 2014: 6; Turner 1997; Hedin et al. 2012; Turner, Whitehead 2002). The MHCs have become forced to act in a more marketminded and business-like manner, which, according to Lind and Lundström (2011) implies that before taking on a project the MHCs must apply the same degree of investment analysis as private companies would do. Borelius and Wennerström (2009) note an increased focus on company branding through changes in the tenant mix.

There exists a system of tenure-neutral rent control and strong security of tenure in the housing sector in Sweden (Kemeny 1995). Until 2011, rents were set through annual local negotiations between the tenants unions and the property federations. The rents in the private sector were capped by those set by the municipal landlords (Wilhelmsson, Klingborg 2011). Changes that came into effect on the $1^{\text {st }}$ January 2011 led to a gradual shift towards a market orientation of the rents (Elsinga, Lind 2013; Pittini, Laino 2011: 32). The housing rent in Sweden is not set according to the current condition of the dwelling but is structured in such a way that it also takes into account the requirements for future maintenance of the flat. Rent increases above the collectively negotiated level (see above), are permissible only in situations in which the standard has been raised (Lind 2014). The rent is inclusive of heating and hot water and only about $1.2 \%$ of the dwellers in flats in Sweden have individual metering and charging (Siggelsten, Olander 2013). There are no laws governing the allocation of private rental dwellings and the selection of tenants in this sector has become more restrictive (Sahlin 2004; Scanlon et al. 2014: 100).

\footnotetext{
${ }^{1}$ Record years is another term that is often used but it covers the period 1961-1975 whereas MHP took place during 1965-1975 (Högberg et al. 2009).
}

\section{LITERATURE REVIEW}

A starting point in order to analyse the factors that influence maintenance costs is to demarcate the term "maintenance" from the terms "operating costs" and "investment". A lot of literature on housing discusses these terms without defining them (see e.g. Zavadskas et al. 2004; Lind 2012). Whereas Goodman (2004) regards repairs and maintenance as part of operating costs, this is not so in Rydell (1971) according to whom utilities and management are operating costs in contrast to maintenance costs. Olanrewaju and AbdulAziz (2015: 81) provide a list of ten definitions of maintenance found in the literature. These vary between companies and within companies (Lind, Muyingo 2012a). In the European standard on maintenance terminology maintenance is defined as the "combination of all technical, administrative and managerial actions during the life cycle of an item intended to retain it in, or restore it to, a state in which it can perform the required function" (CEN 2001). According to Swedish accounting regulations, only costs pertaining to planned maintenance and contained in a long term plan can be categorised as maintenance (Boverket 2002). Lind and Muyingo (2012a) define investments as "resources spent today in order to get some kind of advantage in the future".

Building maintenance costs are generally influenced by factors that can be divided into five main categories: building characteristics, tenant factors, maintainability and maintenance work, political factors and others of a social or legal character (El-Haram, Horner 2002a). Vandalism, overpopulation, changes in maintenance standards and climatic conditions accelerate the need for maintenance activities (Ali et al. 2010; van Mossel, Jansen 2010; Bana e Costa, Oliviera 2002). The quality of the construction and that of the spare parts and materials have a bearing on the frequency of the maintenance actions. Factors such as poor workmanship together with elements of an administrative nature such as budget constraints and poor budgetary control as well as the maintenance organisation's structure and competence of the staff, also influence the amount of maintenance carried out (Boverket 2002; Sharp, Jones 2012). Based on an analysis of life cycle costs a company might choose a construction strategy with high initial capital costs that on the other hand provide lower maintenance costs (Wu et al. 2006).

The goals of the owner will influence the management of the properties. Lind and Blomé (2012) 
find ownership to be of a more speculative and short-term duration in the Swedish private housing sector than within the public sector companies. A higher degree of water leakages in the buildings owned by private property owners was attributed to differences in the maintenance organisations within the public sector companies as compared to those in the private sector (Engvall et al. 2001). According to Borg (2006), some laws and regulations that do not apply to the private property owners curtail the efficiency of the MHCs and lead to increases in their costs. Borg and Lind (2006) note that government policies such as rent regulation influence a company's willingness to carry out costly maintenance. An increase in housing demand in a market under rent control leads to a situation in which a profit-maximising property owner will probably counter an increase in operating costs with a postponement of maintenance measures (Moorhouse 1972; Lind 2014).

Though economies of scale can provide a competitive advantage to large companies in the form of rebates on maintenance materials and services procured in bulk, a portfolio spread over a large geographic area might counteract this effect in case of a centralised organisation. The maintenance costs per unit area for commercial space in Sweden are lower than for flats (Incit 2014a: 65, 2014b: 67).

Building maintenance is either of an acute character necessitating immediate response or of such a nature that it can be planned for. A distinction can be made between corrective maintenance activities and preventive ones. According to Olanrewaju and Abdul-Aziz (2015: 87) preventive maintenance can reduce maintenance costs by $15 \%$ if properly introduced. On the other hand, Lind and Muyingo (2012b) postulate that time-based maintenance, especially in a situation of uncertainty, can lead to unnecessarily carrying out some measures.

\section{QUANTITATIVE ANALYSIS OF THE REPORTED MAINTENANCE COSTS}

Maintenance costs have featured in empirical studies before but mainly as parameters in hedonic price models (see e.g. Wilhelmsson 2008; Knight, Sirmans 1996). El-Haram and Horner (2002a) used a questionnaire survey and an index to examine and rank the factors that could have a significant effect on housing maintenance costs. Moorhouse (1972) used regression and simultaneous modelling to investigate the optimal maintenance undertaken by a property owner in a rent controlled environment. The maintenance expenditure was modelled as a function of net revenue, the size of the building and its age.

Given properties that are comparable in age and structure and assuming that the MHCs and the private housing companies studied in this paper are operated professionally, and with the goals of the owner as a major driving force behind the decisions taken, then based on the literature it could be expected that:

- Maintenance costs are positively correlated with size, age and gross revenue (rent);

- Maintenance costs are negatively correlated with a profit-maximising property owner;

- Maintenance costs are positively correlated to the degree of housing in the portfolio.

The econometric analysis presented here is based on the same model as in Moorhouse (1972) but with an added variable, the ownership category of the company. Thus the model tested is:

$\ln M_{i t}=\beta_{0}+\beta_{1} \ln Y_{i t 1}+\beta_{2} \ln S_{i t 2}+\beta_{3} A_{i t 3}+\beta_{4} C_{i t 4}+e_{i}$.

$i=1, \ldots ., n ; t=1, \ldots ., m$

where: $M$ is a vector of observations of the dependent variable maintenance cost per $\mathrm{m}^{2} ; Y-$ rent revenue; $S$ - size of space under management; $A-$ age of the building under management; $C$ represents the ownership category (municipal or private). Both units of observation $(i)$ and time $(t)$, index the observations where applicable, as some variables vary only across time while others such as the ownership category are fixed in time. On the other hand, maintenance costs can vary over time within the company as well as across the companies.

It is not possible to rule out uncertainty due to omitted variables such as the number of staff per dwelling, and therefore it is difficult to claim that a true model is achieved. Using the log-log form not only helps to deal with possible heteroscedasiticity problems but it also simplifies the interpretation of the regression coefficients. Thus a $1 \%$ increase in $Y$ will lead to a $\beta_{1}{ }^{*} 100 \%$ increase/decrease in $M$. For log-level regressions such as in the case of the ownership category, a unit change in $C$ will lead to a change in $M$ equivalent to $100\left(B_{4}\right)-1$ for values between $-0,1<\beta_{4}>0,1^{2}$.

\subsection{The variables}

The variables used in the analysis are presented in Table 1.

\footnotetext{
${ }^{2}$ For values outside of that range a unit change in the independent variable will lead to a change equivalent to $100 * \beta_{\mathrm{x}} \%$ in the dependent variable.
} 
Table 1. The variables

\begin{tabular}{llll}
\hline Variable & Unit & Definition & $\begin{array}{c}\text { Expected } \\
\text { sign of } \beta\end{array}$ \\
\hline MTNC & $\left(\mathrm{SEK} / \mathrm{m}^{2}\right)$ & Reported maintenance costs for the company's portfolio & \\
DCAT & Binary & Dummy variable for the ownership category, private $=1$. & - \\
AGDHSNG & $\%$ & Ratio of “aged" housing in the portfolio & + \\
RENT & $\mathrm{SEK} / \mathrm{m}^{2}$ & Reported rent revenue for the company's portfolio & + \\
TSPACE & $1000 \mathrm{~m}^{2}$ & Total space under management & + \\
\hline
\end{tabular}

MTNC: This is the dependent variable in the equations estimated and shows the reported yearly maintenance costs in $\mathrm{SEK} / \mathrm{m}^{2}$.

DCAT: The type of ownership category is represented in the model as a dummy variable where 0 is ownership in the municipal sector and 1 is the private rental housing sector. The coefficient is expected to have a negative sign as a change from municipal to private ownership is hypothesised to lead to lower costs.

AGDHSNG: For comparison purposes this variable represents the amount of housing built (or reconstructed) during the period 1961-1975 (termed "aged housing" in this analysis) as a percentage of the total rental space in the company's portfolio each year. It is used as a proxy for age in the model. The data value used here is the same as used by the Swedish tax authorities to denote a building's age with consideration for renovations and any extensions. The coefficient is expected to have a positive sign because as buildings get older the maintenance needed and the related costs are expected to increase.

RENT: This variable represents the reported rent revenue for the company's portfolio in SEK/ $\mathrm{m}^{2}$. An increase in the revenues is expected to lead to a strengthening of the economic base of the company enabling a higher propensity to carry out maintenance activities. Swedish rent control regulations stipulate that maintenance activities are not a basis for raising dwelling rents. Thus, this variable is taken to be exogenous to the reported maintenance costs. The coefficient is expected to have a positive sign in case a stronger economic base leads to more maintenance being carried out.

TSPACE: The variable denoting age in the model is based on the amount of rental housing in the portfolio. However, the companies manage properties in other sectors too and the variable TSPACE represents the total rental space under the company's management. Economies of scale in the maintenance management were taken into consideration but a variable depicting that re- lationship turned out to be highly correlated to TSPACE and was dropped. The coefficient is expected to have a positive sign indicating increases in unit costs due to increases in the space under management.

\subsection{Data collection and descriptive statistics}

In order to carry out the econometric analysis, a sample of housing companies was collected based on two criteria: that the financial reports covering several years were readily available on the internet (a major limitation), and that the maintenance costs were clearly demarcated from repairs and central administration. The initial search returned a total of 46 housing companies. This was narrowed down to 28 (10 private and 18 municipal) as most of the companies failed to fulfil the second criteria. The remaining companies were paired according to location and ownership category. As only a few companies displayed reports older than 2004 the analysis was confined to the period from 2004 to 2007. Data before the global financial crisis in 2008 has the advantage that it refers to a more stable period. Eight pairs that fulfilled all the criteria above were found and used in the analysis.

The econometric analysis was based on unbalanced cross-sectional panel data from the financial reports of the 16 companies for the period 2004 to 2007 whereby $n=64$. The descriptive statistics of the variables used in the analysis are presented in Table 2.

The results indicated a degree of variance between the companies studied especially across the groups but it was less pronounced within the two ownership categories. The very small number of companies in this analysis, due mainly to the second sampling criteria above, further necessitated the need for an analysis based on a larger sample. Therefore, in the subsequent survey the term maintenance was given a wider all-inclusive perspective similar to the definition in the European standard. 
Table 2. Descriptive statistics

\begin{tabular}{lllllll}
\hline Variable & Obs. & Description & Unit & SD & Min & Max \\
\hline MTNC & 54 & Maintenance & SEK $/ \mathrm{m}^{2}$ & 78.9 & 20 & 351 \\
RENT & 56 & Revenue & SEK $/ \mathrm{m}^{2}$ & 275 & 176 & 1388 \\
TSPACE & 58 & Total space & $1000 \mathrm{~m}^{2}$ & 541 & 202 & 2.06 \\
AGDHSNG & 53 & Aged housing & $\%$ & 0.20 & 0.05 & 0.75 \\
DCAT & 64 & Dummy ownership & Binary & 0.50 & 0 & 1 \\
\hline
\end{tabular}

\subsection{Analysis of the results}

The Table 3 presents the results of two equations that were tested, one with, and one without the ownership category. Several equations, some with interactive variables as well as time lags, were tried in a stepwise process but were found to be unsatisfactory.

Table 3. The results of the two regression equations

\begin{tabular}{lllll}
\hline & $\begin{array}{l}(1) \\
\text { coefficient }\end{array}$ & $\mathrm{P}>|\mathrm{z}|$ & $\begin{array}{l}(2) \\
\text { coefficient }\end{array}$ & $\mathrm{P}>|\mathrm{z}|$ \\
\hline Intercept & -5.0279 & 0.061 & -4.3327 & 0.042 \\
lnRENT & 1.0110 & 0.000 & 1.0360 & 0.000 \\
lnTSPACE & 0.4058 & 0.064 & 0.3159 & 0.041 \\
AGDHSNG & 0.8656 & 0.090 & 0.7640 & 0.016 \\
DCAT & & & -0.5155 & 0.023 \\
$\mathrm{R}^{2}$ & 0.47 & & 0.65 & \\
\hline
\end{tabular}

The coefficients are all statistically significant and the inclusion of the variable for the ownership category substantially increased the explanatory power of the model in Equation (2). The signs of the coefficients in the variables presented above are as expected. The result can be written as:

$\log M T N C=-4.33+1.03 \log ($ RENT $)+$

$0.31 \log (T S P A C E)+0.76 A G D H S N G-0.52 D C A T$

The results indicate that an increase in the revenues will lead to a small but relatively higher increase in the reported maintenance costs. It can be argued that if the rent is kept constant in nominal terms then this will lead to a higher degree of neglected maintenance and abandonment as observed in Lind and Blomé (2012) and Lind (2014).

A $10 \%$ increase in the total space under management increases the reported maintenance cost by about $3 \%$, which can be interpreted as an indication of a marginal degree of economies of scale in property maintenance. The reported maintenance cost is expected to increase by slightly less than $8 \%$ if the ratio of aged housing in the portfolio, for example through transactions, increases by $10 \%$. This is consistent with the observation that there is a maintenance backlog in housing built during the period 1961-1975 (Steiner, Ahmadi 2013).
The results further indicate that a switch from public to private housing ownership will lead to a ceteris paribus fall in the reported maintenance costs of about $22 \%^{3}$, a result that is in line with statistic data presented in Statistics Sweden (2012). The analysis confirms that factors such as the age of the building and economies of scale have an influence on the maintenance cost but not as much as the ownership category. Thus, to complement the econometric analysis a survey that focused principally on this factor (ownership category) was carried out.

\section{QUALITATIVE ANALYSIS OF FACTORS INFLUENCING THE MAINTENANCE COSTS REPORTED}

\subsection{Data collection}

Based on the literature review, eight hypotheses that are presented in Table 4 were formulated. Essentially, they elaborate on the five factors that affect maintenance costs as given in El-Haram and Horner (2002a). Non-probability sampling was carried out on rental housing companies that owned buildings constructed in Sweden during the period 1961-1975 in the private as well as public sectors. This produced a list of one hundred and ninety companies whose property managers were contacted. These received an electronic survey consisting of 51 structured questions. The first part of the survey (a-c below) sought answers of an objective nature related to the maintenance strategies of the company. The questions in the second part ( $d$-f below) were of a subjective character with the aim of collecting the opinions of the practitioners whose answers could be compared to those in previous studies such as Borg (2006). The questions were in form of statements to which the respondents could fully agree, fully disagree, or partly agree. In a qualitative descriptive study the focus of the content analysis is on the description of patterns or regularities in the data with the purpose of producing a descriptive summary that

$\overline{3 \mathrm{e}-0.52-1}=0.22$ 
Table 4. The hypotheses behind the questionnaire survey

\begin{tabular}{|c|c|c|}
\hline Factor & Hypothesis & Literature \\
\hline Accounting aspects & $\begin{array}{l}\text { The private companies classify more of their activities as } \\
\text { investment than maintenance }\end{array}$ & Lind and Muyingo (2012a) \\
\hline Budget constraints & $\begin{array}{l}\text { The private companies postpone maintenance in times of } \\
\text { decreasing revenues }\end{array}$ & $\begin{array}{l}\text { Elsinga and Lind (2013) } \\
\text { El-Haram and Horner (2002a) } \\
\text { Borg and Lind (2006) }\end{array}$ \\
\hline Planning of activities & $\begin{array}{l}\text { The public companies base their measures more on long- } \\
\text { term plans thus carrying out unnecessary measures }\end{array}$ & $\begin{array}{l}\text { Sharp and Jones (2012) } \\
\text { Lind and Muyingo (2012b) } \\
\text { Olanrewaju and Abdul-Aziz (2015) }\end{array}$ \\
\hline $\begin{array}{l}\text { Building construction } \\
\text { quality }\end{array}$ & $\begin{array}{l}\text { The buildings in the private sector were built with higher } \\
\text { quality and therefore need less maintenance }\end{array}$ & $\begin{array}{l}\text { Turner }(1997: 479) \\
\text { Wu et al. }(2006)\end{array}$ \\
\hline Tenant composition & $\begin{array}{l}\text { Private companies have better tenants who require less } \\
\text { maintenance }\end{array}$ & $\begin{array}{l}\text { Ali et al. }(2010) \\
\text { Scanlon et al. }(2014: 98)\end{array}$ \\
\hline $\begin{array}{l}\text { Quality of } \\
\text { maintenance }\end{array}$ & $\begin{array}{l}\text { Private companies accept a lower maintenance standard in } \\
\text { their buildings }\end{array}$ & $\begin{array}{l}\text { Moorhouse (1972) } \\
\text { Lind (2014) } \\
\text { Blomé (2012) }\end{array}$ \\
\hline $\begin{array}{l}\text { Efficiency and } \\
\text { procurement } \\
\text { restrictions }\end{array}$ & $\begin{array}{l}\text { Private companies are not restricted by regulations and are } \\
\text { therefore more efficient in their management }\end{array}$ & Borg (2006) \\
\hline External factors & $\begin{array}{l}\text { Politicians and media influence the scheduling of measures } \\
\text { in the public sector raising the costs }\end{array}$ & $\begin{array}{l}\text { Borg and Lind (2006) } \\
\text { El-Haram and Horner (2002a) }\end{array}$ \\
\hline
\end{tabular}

is relevant to the audience for whom it is written (Sandelowski 2000: 339). For the purpose of this analysis, an electronic survey was chosen over interviews as it could provide a cost-effective and speedy form of data collection from respondents over the whole country. The shortcomings of this approach are discussed in section 6 .

\subsection{The results}

Ninety fully completed questionnaires were returned providing a response rate of $46 \%$. Forty per cent of the respondents were from the private sector and $60 \%$ from the public sector. Managers from the 16 companies in the econometric analysis participated in the survey. Due to lack of information it is difficult to compare the group of respondents and the group of non-respondents' and the possibility of a bias cannot be ruled out.

\section{a) Accounting aspects}

The results of the survey indicate a difference in how the private and the municipal housing sectors categorise measures. This appears to vary most in those activities in which some degree of modernisation can lead to all of the costs being capitalised and paid for over a number of years. Activities such as renovation of the façade or the roof that are related to the shell of the building are generally classified by both groups as maintenance. Changes in interior constructions such as the plumbing and ventilation systems are to a much higher extent capitalised and accounted for as investments especially by companies in the private sector. Factors such as the monetary cost for an activity and the size of the activity do not appear to influence the choice between labelling an activity as an operating cost, maintenance cost or investment in both groups. On the other hand, the monetary value of an activity is used more by the public sector than the private sector as a criterion in categorising between an operating cost and a maintenance cost.

When asked to classify façade renovation, pipe replacement, reroofing, and the replacement of the ventilation system, more than $50 \%$ of the respondents in the private sector categorised the measures as investments as compared to about $34 \%$ in the public sector. The company's economic situation did not appear to influence categorisation and the demarcation between maintenance and investment in both groups was at times predetermined for a certain type of activity regardless of what was actually done.

In summary, the hypothesis that private companies classify more as investment appears to be true and can provide part of the answer to the research question.

\section{b) The role of profits}

The period under analysis has in general been a period with falling interest rates and everything else equal the economic surplus of the companies has increased. The second hypothesis implies that this will lead to an increase in maintenance levels especially in the public companies. Ninety three per cent of the public sector respondents 
as compared to $79 \%$ in the private sector agreed with the statement that lower company profits are likely to decrease the company's maintenance efforts. Most of the respondents had been with their company for at least five years and it can be assumed that their response was based on an understanding of the company's long-term strategies. Therefore, the hypothesis that the public sector is more responsive to the budget situation is part of the explanation as to why, in the period investigated, maintenance measures and consequently, the costs, are higher in the public companies.

\section{c) The role of the planning horizon}

The way maintenance activities are scheduled, has an influence on the cost. Table 5 shows that there is a difference between the ownership categories, regarding how the activities are planned and carried out.

The public sector companies appear to have a greater degree of long-term planning and adherence to the plans indicating a time-based maintenance strategy. Inspection is performed more frequently in the private sector signalling a more condition-based maintenance strategy. A difference in maintenance strategies between the sectors offers part of the answer to the research question.

d) The role of building construction quality, tenant composition and maintenance standards

A majority of the respondents in the municipal and the private sectors $(85 \%$ respective $67 \%$ ) found the construction quality of the buildings from the period 1961-1975 to be the same in both sectors. The composition of tenants in these properties was not seen as differing significantly between the sectors though $23 \%$ of the public sector respondents and $8 \%$ in the private sector fully disagreed. $16 \%$ of all of the respondents rejected the statement that private property owners accepted a lower level of maintenance standard in their properties. The results above provide an indication that construction quality; tenant composition and related issues such as tenant demands or vandalism are not taken by the respondents to be major factors behind the differences in reported maintenance costs.

\section{e) Procurement efficiency}

The public sector, unlike the private sector, is subjected to regulations governing tendering and procurement, which at times slows projects and efficiency. According to $85 \%$ of the respondents in the public sector and $54 \%$ in the private sector, municipal companies are as effective in procurement as their private sector counterparts and this cannot be seen as a possible explanation for the differences in the reported maintenance costs.

f) External factors: the role of politicians and journalists

El-Haram and Horner (2002a) find political policies, such as the right to buy, to have a major effect on maintenance levels in the public housing sector. One out of four participants in both categories fully agreed that the difference in the reported maintenance costs can be attributed to the municipal companies carrying out unprofitable activities that a private company would not do. As shown in Table 6 , close to $40 \%$ of the respondents in the private sector as well as about $25 \%$ of the respondents from the public sector were of the opinion that this is due to pressure by politicians and the media. A majority of the participants partly agreed that this is the case.

The results in the second part of the survey $(d-f)$ indicate that though building construction quality, tenant composition, procurement efficiency and the role of politicians and the media, are factors that affect maintenance costs, the hypotheses that they are outstanding reasons for the observed differences in the reported maintenance costs between the ownership groups can be rejected.

Table 5. Maintenance planning and strategies

\begin{tabular}{|c|c|c|c|c|}
\hline Statement & $\begin{array}{l}\text { Fully } \\
\text { agree }\end{array}$ & $\begin{array}{l}\text { Public } \\
\text { sector } \\
\text { answers }\end{array}$ & $\begin{array}{l}\text { Private } \\
\text { sector } \\
\text { answers }\end{array}$ & Total \\
\hline \multirow[t]{2}{*}{ We have an overall maintenance plan that is longer than 5 years } & Yes & $66 \%$ & $28 \%$ & $50 \%$ \\
\hline & No & $29 \%$ & $69 \%$ & $46 \%$ \\
\hline $\begin{array}{l}\text { More than } 75 \% \text { of the activities in the current year were part of the maintenance } \\
\text { plan done } 1 \text { year ago }\end{array}$ & Yes & $70 \%$ & $47 \%$ & $61 \%$ \\
\hline $\begin{array}{l}\text { Less than } 50 \% \text { of the activities in the current year were part of the maintenance } \\
\text { plan done } 1 \text { year ago }\end{array}$ & Yes & $18 \%$ & $17 \%$ & $18 \%$ \\
\hline We inspect our buildings annually & Yes & $41 \%$ & $67 \%$ & $52 \%$ \\
\hline We inspect certain components in our buildings continually & Yes & $57 \%$ & $70 \%$ & $62 \%$ \\
\hline
\end{tabular}


Table 6. External pressure makes public companies carry out measures too early

\begin{tabular}{lllll}
\hline Statement & Fully agree & $\begin{array}{l}\text { Public } \\
\text { respondents }\end{array}$ & $\begin{array}{l}\text { Private } \\
\text { respondents }\end{array}$ & Total \\
\hline $\begin{array}{l}\text { Municipal housing companies carry out ef- } \\
\text { forts that are not profitable and that a pri- }\end{array}$ & Yes & $26 \%$ & $29 \%$ & $28 \%$ \\
$\begin{array}{l}\text { vate property owner would not do } \\
\begin{array}{l}\text { The municipal housing companies are } \\
\text { forced to carry out actions that are not prof- }\end{array}\end{array}$ & Yes & $24 \%$ & $15 \%$ & $21 \%$ \\
$\begin{array}{l}\text { itable due to pressure from politicians and } \\
\text { the media }\end{array}$ & & $24 \%$ & $37 \%$ & $29 \%$ \\
\hline
\end{tabular}

\section{DISCUSSION AND CONCLUSION}

The results from the quantitative and the qualitative analyses indicate that the higher maintenance costs in the public companies are related principally to the ownership category and that the main underlying factors seem to be that the private companies tend to:

- classify more activities as investment than maintenance;

- evaluate the optimal timing of carrying out a measure in a different way.

How activities are classified is of importance in the debate on how to finance the required maintenance and renovations as property owners might shy away from necessary measures if they cannot raise the rent (Lind 2014). The second point is perhaps the most important and it is the related to several of the more specific results presented above. There is an indication that private companies do not spend more on maintenance just because they can afford it. The opinion is that they do not have pressure to renovate if it is not profitable. Another way to put this is that the private companies demand a higher rate of return on their investment and that they are more consistent over time in applying this rate of return. The private companies seem to apply a more reactive than preventive approach to maintenance.

Subjective responses are difficult to quantify and to relate directly to the observed maintenance costs. However they provide an indication of factors that could be of interest in further studies. Lind et al. (2014: 8) as well as Scanlon et al. (2014: 101) provide evidence that decisions about activities in some MHCs are determined by the political majority in the municipality. The study reported in Lind et al. (2014: 18) reveals that the measures carried out were not economically profitable and that there are no plans to carry out renovation on part of the stock that was privatised. Despite directives towards a more business-like approach within the MHC it is clear that principal-agency problems in form of external pressure within the publicly owned housing sector influence the scheduling of some maintenance measures which might affect the costs reported in comparison to the private sector. As noted in El-Haram and Horner (2002a), political factors affect maintenance costs. They are difficult to quantify and their relation with the reported costs might be disputable. Nevertheless, they provide an example of factors that cannot be ignored in the search for the answer as to why Swedish public sector housing companies consistently report higher maintenance costs than their counterparts in the private sector.

The results from this paper are important in relation to several current discussions concerning the large housing stock that is believed to be in need of renovation. The first is that maybe the maintenance backlog in the public housing stock is not as large as imagined. The public companies instead seem to do things earlier than the private owners - and remember that there is probably a bias in the sample towards more long-term private companies. If the private companies are assumed to make rational choices from a profit maximizing perspective, then maybe the public companies are doing things too early. An explanation could be that the low interest rate in recent years has created a surplus that has made this possible.

Since 2011 public housing companies in Sweden are obliged to operate in a "business efficient manner" and this has been interpreted as "behaving as a long-term private actor would do". The results above mean that the public companies should look closer at the strategies of the private companies; that they should wait longer than they currently do before carrying out renovations; and that they should be more stringent in their evaluation of how the resources should be spent.

Due to the limitations of the analyses carried out in this paper, the results should not be viewed as a means of quantifying the gap between the sectors in absolute terms but as evidence of its 
existence, and probable reasons as to why it exists. There is a need to improve the chosen research method if it is to sufficiently reveal the differences between the public and the private sectors. The lack of detailed information about the companies such as the size of the staff involved in the maintenance work per unit area under management and the specific measures carried out in the buildings are major factors missing in the data and detailed information that can be acquired through interviews is lost when a questionnaire survey method is chosen. An example is that the qualitative analysis indicates a higher reduction in maintenance effort within the private sector in case of lower profits. However, a company bent on long term ownership but with a low maintenance level would probably not decrease its efforts. Similarly, biasness in the response to the statement that the private sector accepts a lower level of maintenance standard could be reduced through follow-up questions.

There is a need for strategies that can lead to more efficient housing maintenance management within the public sector that at times is seen as wasteful (Sharp, Jones 2012). This paper presents some suggestions as to what could possibly be done by the MHCs in order to reduce the variance in the reported maintenance costs between the sectors analysed. However, in order to properly identify the cost-drivers in the two sectors, an extension of the findings in this paper would be to carry out a systematic evaluation of maintenance costs per maintenance task in both ownership categories, similar to the RCM process proposed in El-Haram and Horner (2002b). The lessons learned can then be utilised even in measures aimed at raising energy efficiency within the housing sector.

\section{REFERENCES}

Ali, A. S.; Kamaruzzaman, S. N.; Sulaiman, R.; Peng, Y. C. 2010. Factors affecting housing maintenance cost in Malaysia, Journal of Facilities Management 8(4): 285-298. https://doi.org/10.1108/14725961011078990

Andersson, R.; Turner, L. M. 2014. Segregation, gentrification, and residualisation: from public housing to market-driven housing allocation in inner city Stockholm, International Journal of Housing Policy 14(1): 3-29. https://doi.org/10.1080/14616718.2013.872949

Baek, C. H.; Park, S. H. 2012. Changes in renovation policies in the era of sustainability, Energy and Buildings 47: 485-496. https://doi.org/10.1016/j.enbuild.2011.12.028

Balaras, C. A.; Droutsa, K.; Dascalaki, E.; Kontoyiannidis, S. 2005. Deterioration of European apartment buildings, Energy and Buildings 37(5): 515-527. https://doi.org/10.1016/j.enbuild.2004.09.010

Ball, M. 2012. European housing review 2012. London: RICS Research.

Bana e Costa, C.; Oliviera, R. 2002. Assigning priorities for maintenance, repair and refurbishment in managing a municipal housing stock, European Journal of Operational Research 138: 308-391.

https://doi.org/10.1016/S0377-2217(01)00253-3

Blomé, G. 2010. Local housing administration models for large housing estates, Property Management 28(5): 320-338. https://doi.org/10.1108/02637471011086527

Borelius, U.; Wennerström, U. B. 2009. A new Gårdsten: a case study of a Swedish municipal housing company, International Journal of Housing Policy 9; 223-239. https://doi.org/10.1080/14616710902920330

Borg, L. 2006. De allmännyttiga bostadsföretagens framtid. Stockholm: KTH Royal Institute of Technology.

Borg, L.; Lind, H. 2006. De allmännyttiga bostadsföretagens roll på bostadsmarknaden. Stockholm: s.n.

Botta, M. 2005. Towards sustainable renovation three research projects. Stockholm: KTH Royal institute of Technology.

Boverket. 2002. Bättre koll på underhåll. Karlskrona: Boverket - The Swedish National Board of Housing, Building and Planning.

CEN. 2001. EN 13306:2001 Maintenance terminology. Brussels: European Committee for Standardisation.

Creswell, J. W. 2013. Research design: qualitative, quantitative, and mixed methods approaches. $4^{\text {th }}$ ed. Sage publications.

Crook, T.; Kemp, P. A. 2014. Private rental housing: comparative perspectives. Cheltenham: Edward Elgar Publishing. https://doi.org/10.4337/9781781954164

Dol, K.; Haffner, M. 2010. Housing statistics in the European Union 2010. Hague: The Hague, Ministry of the Interior and Kingdom Relations.

El-Haram, M. A.; Horner, R. 2002a. Factors affecting housing maintenance cost, Journal of Quality in Maintenance Engineering 8(2): 115-212. https://doi.org/10.1108/13552510210430008

El-Haram, M.; Horner, R. 2002b. Practical application of RCM to local authority housing: a pilot study, Journal of Quality in Maintenance Engineering 8(2): 135-143. https://doi.org/10.1108/13552510210429992

Elsinga, M.; Lind, H. 2013. The effect of EU-legislation on rental systems in Sweden and the Netherlands, Housing Studies 28: 960-970. https://doi.org/10.1080 /02673037.2013.803044

Engvall, K.; Norrby, C.; Norbäck, D. 2001. Sick building syndrome in relation to building dampness in multi-family residential buildings in Stockholm, International Archives of Occupational and Environmental Health 74: 270-278. https://doi.org/10.1007/ s004200000218

Goodman, J. 2004. Determinants of operating costs of multifamily rental housing, Journal of Housing Economics 13: 226-244. https://doi.org/10.1016/j. jhe.2004.07.003

Haffner, M. 2012. Housing tenures in comparison - the European Union [online]. Available at: http://hofinet. 
org/themes/theme.aspx?tid=94\&id=106 [accessed 14 October 2012]

Hall, T.; Vidén, S. 2005. The Million Homes Programme: a review of the great Swedish planning project, Planning Perspectives 20(3): 301-328. https://doi.org/10.1080/02665430500130233

Hedin, K.; Clark, E.; Lundholm, E.; Malmberg, G. 2012. Neoliberalization of housing in Sweden: gentrification, filtering, and social polarization, Annals of the Association of American Geographers 102(2): 443463. https://doi.org/10.1080/00045608.2011.620508

Hedman, E. 2008. A history of the Swedish system of non-profit municipal housing. Karlskrona Sweden: Boverket - The Swedish National Board of Housing, Building and Planning.

Högberg, L. 2014. Who will close the energy efficiency gap? A quantitative study of what characterizes ambitious housing firms in Sweden, in Building sustainability - studies on incentives in construction and management of real estate. Doctoral Thesis. Stockholm: KTH The Royal Institute of Technology.

Högberg, L.; Lind, H.; Grange, K. 2009. Incentives for Improving energy efficiency when renovating largescale housing estates: a case study of the Swedish Million Homes Programme, Sustainability 1(4): 1349-1365. https://doi.org/10.3390/su1041349

Incit. 2014a. REPAB fakta årskostnader bostäder. Mölndal: Incit AB.

Incit. 2014b. REPAB fakta årskostnader kontor. Mölndal: Incit AB.

Kemeny, J. 1995. From public housing to the social market: rental policy strategies in comparative perspective. London: Routledge. https://doi.org/10.4324/9780203308554

Knight, J. R.; Sirmans, C. F. 1996. Depreciation, maintenance, and housing prices, Journal of Housing Economics 5: 369-389. https://doi.org/10.1006/ jhec.1996.0019

Lind, H. 2012. Pricing principles and incentives for energy efficiency investments in multi-family rental housing: the case of Sweden, Energy Policy 49: 528 530. https://doi.org/10.1016/j.enpol.2012.06.054

Lind, H. 2014. The effect of rent regulations and contract structure on renovation: a theoretical analysis of the Swedish system [online]. Available at: http://www. diva-portal.org/smash/record.jsf?pid=diva2\%3A7583 $15 \& d s w i d=7758$ [accessed 15 April 2015]

Lind, H.; Annadotter, K.; Björk, F.; Högberg, L.; Klintberg, T. 2014. Sustainable renovation strategy in the Swedish Million Homes Programme: a case study, in Building Sustainability. Stockholm: School of Architecture and the Built Environment, KTH Royal Institute of Technology.

Lind, H.; Blomé, G. 2012. Slumlords in the Swedish welfare state: how is it possible?, International Journal of Housing Markets and Analysis 5(2): 196-210. https://doi.org/10.1108/17538271211225931

Lind, H.; Lundström, S. 2011. Hur ett affärsmässigt bostadsföretag agerar. Stockholm: s.n.

Lind, H.; Muyingo, H. 2012a. Critical reflections on the concept of maintenance, International Journal of Strategic Property Management 16(2): 105-114. https://doi.org/10.3846/1648715X.2011.626463

Lind, H.; Muyingo, H. 2012b. Building maintenance strategies: planning under uncertainty, Property Management 30(1): 14-28. https://doi.org/10.1108/02637471211198152

Meijer, F.; Itard, L.; Sunikka-Blank, M. 2009. Comparing European residential building stocks: performance, renovation and policy opportunities, Building Research \& Information 37(5-6): 533-551. https://doi.org/10.1080/09613210903189376

Moorhouse, J. C. 1972. Optimal housing maintenance under rent control, Southern Economic Journal 39(1): 93-106. https://doi.org/10.2307/1056228

Olanrewaju, A.; Abdul-Aziz, A. R. 2015. Building maintenance processes, principles, procedures, practices and strategies, in Building Maintenance Processes and Practices. Singapore: Springer, 79-125.

https://doi.org/10.1007/978-981-287-263-0_5

Pittini, A.; Laino, E. 2011. Housing Europe review 2012. The nuts and bolts of European social housing systems [online]. Available at: http://www.housingeurope.eu/www.housingeurope.eu/uploads/file_/ HER\%202012\%20EN\%20web2_1.pdf. [accessed 25 April 2015]

Rydell, P. 1971. Review of factors affecting maintenance and operating costs in public housing, Papers in Regional Science 27(1): 229-246. https://doi.org/10.1007/ BF01954608

SABO. 2009. Hem för miljoner - förutsättningar för upprustning av rekordårens bostäder. Stockholm: SABO.

Sahlin, I. 2004. Central state and homelessness policies in Sweden: new ways of governing, International Journal of Housing Policy 4: 345-367.

Sandelowski, M. 2000. Whatever happened to qualitative description?, Research in Nursing \& Health 23: 334-340. https://doi.org/10.1002/1098240X(200008)23:4<334::AID-NUR9>3.0.CO;2-G

Scanlon, K.; Whitehead, C.; Arrigoitia, M. F. 2014. Social housing in Europe. West Sussex, United Kingdom: John Wiley \& Sons. https://doi.org/10.1002/9781118412367

Scanlon, K.; Whitehead, C.; Arrigoitia, M. F. 2015. Social housing in Europe, European Policy Analysis 17: $1-12$.

Sharp, M.; Jones, K. 2012. Perceived inefficiency in social housing maintenance, Construction Innovation 12(4): 414-428. https://doi.org/10.1108/14714171211272199

Siggelsten, S.; Olander, S. 2013. Individual metering and charging of heat and hot water in Swedish housing cooperatives, Energy Policy 61: 874-880. https://doi.org/10.1016/j.enpol.2013.06.083

Statistics Sweden. 2012. Revenues and expenditure survey for multi-dwelling buildings [online]. Available at: http://www.scb.se/Pages/TableAndChart__29334.aspx [accessed 25 March 2013]

Statistics Sweden. 2013. Yearbook of housing and building statistics 2012 [online]. Available at: http://www. scb.se/statistik/_publikationer/BO0801_2012A01_ BR_BO01BR1201.pdf [accessed 2 September 2015] 
Steiner, L.; Ahmadi, Z. 2013. Renewal of the Swedish Million Dwelling Program, the public housing company and the local community, hindrances and mutual aid, World Academy of Science, Engineering and Technology 76: 360-366.

Tagesson, T.; Eriksson, O. 2011. What do auditors do? Obviously they do not scrutinise the accounting and reporting, Financial Accountability \& Management 27(3): 272-285. https://doi.org/10.1111/j.14680408.2011.00525.x

Thollander, P.; Rohdin, P.; Moshfegh, B. 2012. On the formation of energy policies towards 2020: challenges in the Swedish industrial and building sectors, Energy Policy 42: 461-467. https://doi.org/10.1016/j. enpol.2011.12.012

Turner, B. 1997. Municipal housing companies in Sweden: on or off the market?, Housing Studies 12(4): 477-488. https://doi.org/10.1080/02673039708720911

Turner, B.; Whitehead, C. M. E. 2002. Reducing housing subsidy: Swedish housing policy in an international context, Urban Studies 39(2): 201-217.

https://doi.org/10.1080/00420980120102920 van Mossel, H. J.; Jansen, S. J. 2010. Maintenance services in social housing: what do residents find important?, Structural Survey 3(28): 215-229. https://doi.org/10.1108/02630801011058942

Wilhelmsson, M. 2008. House price depreciation rates and level of maintenance, Journal of Housing Economics 17: 88-101. https://doi.org/10.1016/j. jhe.2007.09.001

Wilhelmsson, M. A. R.; Klingborg, K. 2011. Rent control and vacancies in Sweden, International Journal of Housing Markets and Analysis 4: 105-129. https://doi.org/10.1108/17538271111137903

Wu, S.; Clements-Croome, D.; Fairey, V.; Albany, B.; Sidhu, J.; Desmond, D.; Neale, K. 2006. Reliability in the whole life cycle of building systems, Engineering, Construction and Architectural Management 13(2): 136-153. https://doi.org/10.1108/09699980610659607

Zavadskas, E. K.; Kaklauskas, A.; Raslanas, S. 2004. Evaluation of investments into housing renovation, International Journal of Strategic Property Management 8: 177-190. 